\title{
Who bears the cost of forest conservation?
}

\author{
Mahesh Poudyal ${ }^{1}$ ， Julia P G Jones ${ }^{\text {Corresp., }}{ }^{1}$ ， Sarobidy $O$ Rakotonarivo ${ }^{2}$, Neal Hockley ${ }^{1}$, James M Gibbons ${ }^{1}$ \\ Rina Mandimbiniaina ${ }^{3}$, Alexandra Rasoamanana ${ }^{3}$, Nilsen S Andrianantenaina ${ }^{3}$, Bruno S Ramamonjisoa \\ ${ }^{1}$ School of Environment, Natural Resources and Geography, Bangor University, Bangor, United Kingdom \\ 2 Biological and Environmental Sciences, University of Stirling, Stirling, United Kingdom \\ 3 Département des Eaux et Forêts, Ecole Supérieure des Sciences Agronomiques, Université d'Antananarivo, Antananarivo, Madagascar \\ Corresponding Author: Julia P G Jones \\ Email address: julia.jones@bangor.ac.uk
}

Background. While the importance of conserving ecosystems for sustainable development is widely recognized, it is increasingly evident that despite delivering global benefits, conservation often comes at local cost. Protected areas funded by multilateral lenders have explicit commitments to ensure that those negatively affected are adequately compensated. We make the first comparison of the magnitude and distribution of the local costs of a protected area with the magnitude and distribution of the compensation provided under the World Bank social safeguard policies (Performance Standard 5). Methods. In the Ankeniheny-Zahamena Corridor (a new protected area and REDD+ pilot project in eastern Madagascar), we used choice experiments to estimate local opportunity costs $(n=453)$ which we annualized using a range of conservative assumptions concerning discount rates. Detailed surveys covering farm inputs and outputs as well as off-farm income $(n=102)$ allowed us to explore these opportunity costs as a proportion of local incomes. Intensive review of publically available documents provided estimates of the number of households that received safeguard compensation and the amount spent per household. We carried out a contingent valuation exercise with beneficiaries of this compensation two years after the micro-development projects were implemented $(n=62)$ to estimate their value as perceived by beneficiaries. Results. Conservation restrictions result in very significant costs to forest communities. The median net present value of the opportunity cost across households in all sites was US $\$ 2,375$. When annualized, these costs represent $27-84 \%$ of total annual income for median-income households; significantly higher proportionally for poorer households. Although some households have received compensation, we conservatively estimate that more than $50 \%$ of eligible households (3,020 households) have not. Given the magnitude of compensation (based both on amount spent and valuation by recipients two years after the compensation was distributed) relative to costs, we argue that no one was fully compensated. Achieving full compensation will require an order of magnitude more than was spent but we suggest that 
this should be affordable given the global value of forest conservation. Discussion. By analyzing in unprecedented depth both the local costs of conservation, and the compensation distributed under donor policies, we demonstrate that despite wellintentioned policies, some of the poorest people on the planet are still bearing the cost of forest conservation. Unless significant extra funding is provided by the global beneficiaries of conservation, donors' social safeguarding requirements will not be met, and forest conservation in developing countries will jeopardize, rather than contribute to, sustainable development goals. 


\section{Who bears the cost of forest conservation?}

2

3 Mahesh Poudyal $^{1}$, Julia Patricia Gordon Jones ${ }^{1}$, O. Sarobidy Rakotonarivo ${ }^{1,2}$, Neal Hockley ${ }^{1}$,

4 James Michael Gibbons ${ }^{1}$, Rina Mandimbiniaina ${ }^{3}$, Alexandra Rasoamanana ${ }^{3}$, Nilsen Spener

5 Andrianantenaina ${ }^{3}$, Bruno Solomon Ramamonjisoa ${ }^{3}$

$6{ }^{1}$ School of Environment, Natural Resources and Geography, Bangor University, Bangor, Wales, 7 UK

$8 \quad 2$ Biological and Environmental Sciences, University of Stirling, Stirling, Scotland, UK

$9{ }^{3}$ Département des Eaux et Forêts, Ecole Supérieure des Sciences Agronomiques, Université

10 d'Antananarivo, Antananarivo, Madagascar

12 Corresponding author:

13 Julia P.G. Jones ${ }^{1}$

14 Julia.jones@bangor.ac.uk 
16 Abstract

17 Background. While the importance of conserving ecosystems for sustainable development is widely recognized, it is increasingly evident that despite delivering global benefits, conservation often comes at local cost. Protected areas funded by multilateral lenders have explicit commitments to ensure that those negatively affected are adequately compensated. We make the first comparison of the magnitude and distribution of the local costs of a protected area with the magnitude and distribution of the compensation provided under the World Bank social safeguard policies (Performance Standard 5).

Methods. In the Ankeniheny-Zahamena Corridor (a new protected area and REDD+ pilot project in eastern Madagascar), we used choice experiments to estimate local opportunity costs $(n=453)$ which we annualized using a range of conservative assumptions concerning discount rates. Detailed surveys covering farm inputs and outputs as well as off-farm income $(n=102)$ allowed us to explore these opportunity costs as a proportion of local incomes. Intensive review of publically available documents provided estimates of the number of households that received safeguard compensation and the amount spent per household. We carried out a contingent valuation exercise with beneficiaries of this compensation two years after the micro-development projects were implemented $(n=62)$ to estimate their value as perceived by beneficiaries.

Results. Conservation restrictions result in very significant costs to forest communities. The median net present value of the opportunity cost across households in all sites was US $\$ 2,375$. When annualized, these costs represent $27-84 \%$ of total annual income for median-income households; significantly higher proportionally for poorer households. Although some households have received compensation, we conservatively estimate that more than $50 \%$ of eligible households (3,020 households) have not. Given the magnitude of compensation (based both on amount spent and valuation by recipients two years after the compensation was distributed) relative to costs, we argue that no one was fully compensated. Achieving full compensation will require an order of magnitude more than was spent but we suggest that this should be affordable given the global value of forest conservation.

Discussion. By analyzing in unprecedented depth both the local costs of conservation, and the compensation distributed under donor policies, we demonstrate that despite well-intentioned policies, some of the poorest people on the planet are still bearing the cost of forest conservation. 
Unless significant extra funding is provided by the global beneficiaries of conservation, donors' social safeguarding requirements will not be met, and forest conservation in developing countries will jeopardize, rather than contribute to, sustainable development goals.

\section{Introduction}

Over the past two decades a series of high profile initiatives have highlighted the links between environmental conservation and human well-being (e.g. Millennium Ecosystem Assessment, 2005; TEEB, 2010). The UN Sustainable Development Goals (SDGs), which were agreed by the United Nations in 2015, have embedded into international policy the view that ending poverty cannot be achieved without tackling climate change and conserving and restoring ecosystems (Martinez \& Mueller, 2015; Gupta \& Vegelin, 2016). The loss of tropical forests, for example, has significant societal costs: deforestation and degradation is estimated to contribute $8-10 \%$ of global net carbon emissions (Baccini et al., 2012; Tubiello et al., 2015), forests contain highly valued biodiversity (Mittermeier et al., 1998) and contribute to regional hydrological cycles (Lawrence \& Vandecar, 2015). For this reason, the sustainable management of forests received special mention in the SDGs (Goal 15). However, the conservation of tropical forests can often have local costs, including physical and economic displacement of people (Balmford \& Whitten, 2003; Agrawal \& Redford, 2009; Adams, Pressey \& Naidoo, 2010; Fisher et al., 2011; Green et al., 2018).

There is longstanding recognition that steps should be taken to ensure that the global good of conservation is not paid for by those least able to bear additional costs. For example, the principle that protected areas should do no harm to local people was established at the World's Park Congress in 2003 (Pullin et al., 2013). The Convention on Biological Diversity (CBD COP5 Decision V/6) and Aichi Target 11 both require protected area management to be "fair and equitable" (UNEP/CBD, 2000). Increasingly, conservation is funded by major international donors who have explicit commitments to safeguard against negative social impacts. For example, many Reducing Emissions from Deforestation and Forest Degradation (REDD+) pilot projects have been funded by the World Bank (through their Forest Carbon Partnership Facility or other schemes), while major industrial investments such as mines are funding the creation of biodiversity offsets so as to achieve 'no net loss' of biodiversity in their operations (Bidaud et al., 
2018). The majority of financial institutions (covering more than $70 \%$ of international project finance debt in emerging markets) have committed to the equator principles (Anonymous, 2013). These require projects in countries without robust environmental and social governance to follow the stringent performance standards of the International Finance Corporation; all World Bank projects also follow these standards. Performance Standard 5 states than where people are displaced, physically or economically, they must be compensated for any losses (IFC, 2012). However, despite these clear commitments to compensation of the local costs of conservation, we know of no example where the magnitude and distribution of the local costs of a conservation project have been estimated and compared with the magnitude and distribution of the compensation delivered.

Madagascar is world renowned for the exceptional biodiversity of its forests making it a focus of conservation attention for decades. In 2003 Madagascar made a high profile announcement that it would triple the size of its protected area network (Gardner et al., 2013); a process which led to the creation of around 100 new protected areas which were finally approved in May 2015 (Republic of Madagascar, 2015a). Madagascar has also been at the vanguard of efforts to pilot the climate mitigation mechanism of REDD + , and REDD+ formed part of the country's Individual Nationally Determined Contribution to the Paris climate agreement (Republic of Madagascar, 2015b). Madagascar is an extremely poor country with the second highest proportion of its citizens classed as 'extremely poor' of any country in the world (World Bank, 2017a). Under both Malagasy law, and the requirements of international lenders, new protected areas in Madagascar require an environmental and social impact assessment which identifies who should receive compensation for economic displacement under social safeguard procedures and presents a strategy for delivering such compensation.

It is well understood that human well-being is a multidimensional concept encompassing material, social and subjective components (Woodhouse et al., 2015). Local costs of conservation will not be limited to tangible impacts such as reduced food production: enforced cessation of activities like swidden agriculture may also result in cultural losses. Monetary valuation is one way of bringing together multiple considerations onto a single scale. Discrete Choice Experiments (called choice experiments for the rest of this paper) are a stated preference method which allows estimates of the welfare effects of a project or policy and, crucially, to 
105 estimate separately the values of the attributes that characterize that policy (Hanley, Wright \& 106 Adamowicz, 1998). While the hypothetical nature of stated preference methods has been long

107

108 criticized (Hausman, 2012), there have been increasing efforts to tackle various issues with their reliability and validity (e.g. Hanley et al., 1998; Louviere et al., 2011, 2000). With careful design and rigorous field testing, choice experiments can be a useful method for elucidating opportunity costs of land use change or conservation restrictions even in rural areas with limited market integration and low literacy (Kenter et al., 2011; Kaczan, Swallow \& Adamowicz, 2013; Nielsen, Jacobsen \& Thorsen, 2014; Rakotonarivo, Schaafsma \& Hockley, 2016). A particular advantage to using choice experiments for valuing sensitive activities such as illegal forest clearance is that policy impacts are inferred from the trade-offs that respondents make, meaning researchers can avoid asking direct questions about the policy being valued (Rakotonarivo, Schaafsma \& Hockley, 2016; Nielsen, Jacobsen \& Thorsen, 2014; Moros, Velez \& Corbera, 2017).

In this study we use a carefully designed choice experiment (the repeatability and validity of which had been extensively tested: Rakotonarivo et al., 2018, 2017), to estimate the welfare impacts of forest conservation to people surrounding a new protected area and REDD+ pilot project (the Ankeniheny-Zahamena Corridor - CAZ), and contiguous long-established protected areas, in eastern Madagascar (Fig. 1). We estimate the magnitude of local opportunity costs of preventing swidden agriculture on forestlands (commonly cited as the major threat to forest in the region; Styger et al., 2007; Tabor et al., 2017), how these costs are distributed across local households, and the magnitude of these costs in terms of local incomes. We compare our opportunity cost estimates with the estimates produced by the World Bank social safeguard procedures, the money allocated to compensate households, and the value of the compensation that was received (estimated by a contingent valuation exercise).

\section{Materials and Methods}

\section{Study area}

The Ankeniheny-Zahamena Corridor (French acronym: CAZ) is a 382,000 ha belt of rainforest in eastern Madagascar linking a number of existing protected areas. It was granted formal status as an IUCN category VI protected area in April 2015. It is also a REDD+ pilot project and received certification to deliver 10 million metric tons of avoided $\mathrm{CO}_{2}$ emissions from Verified 
134 Carbon Standard (VCS) over the first ten year period (Rainforest Alliance, 2013). The habitat is

135 humid rain forest and the CAZ and its adjacent long-established protected areas are among the

136 world's most irreplaceable in terms of biodiversity conservation (Le Saout et al., 2013). The

137 forests are under pressure from expansion of agricultural land (mostly small-scale swidden

138 agriculture), illegal logging and mining (Ratsimbazafy, Harada \& Yamamura, 2011; Tabor et al.,

139 2017). Swidden agriculture (the local system of which is known as tavy, or teviala when

140 referring specifically to clearing forestlands) has been the major focus of conservation attention

141 in Madagascar's eastern rain forests for decades (Scales, 2014). Since colonial times, forest

142 clearance for swidden agriculture has been at times both criminalized and encouraged in

143 Madagascar and enforcement of the current ban is weak, even in long-established protected areas

144 (Kull 2004).

145

146

147

Around 450 villages surrounding the protected area contain more than 60,000 people who depend primarily on swidden agriculture, and on collecting products from the wild (World Bank, 2012). They are mostly extremely poor and highly vulnerable to economic or environmental shocks (Harvey et al., 2014). As in many other parts of the world (White \& Martin, 2002) all forested lands in Madagascar have been formally considered as state land since the colonial era (Horning, 2005). However state ownership is often not recognized as legitimate by local communities and an informal system based on customary rights operates in practice (Antona et al., 2004; Pollini et al., 2014) evolving and adapting in response to state claims and activities (Muttenzer, 2006; Jones et al., 2018).

The CAZ protected area was established with funding provided through the third phase of Madagascar's environmental plan (PE3; World Bank, 2016). The World Bank requires that all projects carry out social safeguards assessment to identify and mitigate any residual social impacts (Lockwood \& Quintela, 2006). The CAZ environmental and social safeguards plan (World Bank, 2012) follows the World Bank guidelines and PE3 framework in laying out the process of identifying and compensating households identified as project affected persons (known commonly as PAPs, but referred to as eligible for compensation in this paper to minimize jargon). Both the PE3 framework and CAZ safeguards plan state that anyone whose sources of income and standard of living would be negatively affected by the restriction of access to the natural resources due to the creation of these protected areas are considered eligible 
164 for compensation (ibid.). These documents also specify the need to give special consideration to 165 poor and vulnerable groups; a principle which is central to social safeguards of any World Bank 166 funded project (Hall, 2007). The initial safeguard assessment was conducted in 2010 and 167 identified 2500 households eligible for compensation in 33 fokontany (the smallest

168 administrative unit in Madagascar). Compensation based on micro-development projects such as improved agriculture, small-scale livestock and beekeeping projects (MEEF/SAPM/CI, 2013) started to be distributed in 2014 (soon after the first phase of fieldwork for this survey was 171 conducted).

\section{Sampling}

173 Following pilot surveys in two areas (see Fig. 1) and reconnaissance visits to a number of others, 174 we purposively selected four sites surrounding the CAZ and adjacent long-established protected areas (see Fig. 1 and Table 1). We selected two sites affected by the new CAZ protected area; one of which received compensation under the World Bank social safeguards scheme (in Ampahitra fokontany) and one which did not (Sahavazina fokontany). Because past exposure to conservation may affect respondents' stated preferences (Rakotonarivo et al., 2017), we also selected two sites with a long history of conservation under the management of Madagascar National Parks (MNP): Zahamena National Park (which has been mostly under some form of conservation management since 1927; Raboanarielina, 2012), and Mantadia National Park (which was established in 1989; Shyamsundar, 1996). Sites managed by MNP receive development interventions funded through the distribution of $50 \%$ of park entrance fees. Available information on the location and size of communities in much of rural Madagascar is very sparse making it difficult to develop a rigorous sampling frame (Poudyal et al. 2016). Using the available maps as a starting point, we worked with key informants to construct a sketch map showing locations of all villages in each study area. We visited each village, mapped the hamlets and scattered households with the help of key informants and visited the hamlets to map their location with a GPS, confirm the number of households present and ask for information of other households we may have missed. Once we had a complete sampling frame we selected our sample and an additional 10\% percent to replace households which could not be reached or declined to take part in the survey. Because of the importance of ensuring our sample is fully 
193 representative we devoted substantial time to building the sampling frame; this took up to $30 \%$

194 of total field time in each site.

\section{Data collection}

196

Data for this study was collected through detailed surveys carried out in three phases (see Supplemental Information for copies of all survey instruments in English and Malagasy). First, a general household survey was done with the sample as outlined in Table 1 (July 2014 to March 2015). The survey comprised two sections: 1) Socio-economic characteristics of the household including composition, education, wealth indicators (such as land and livestock holdings, house quality and size, access to light); 2) the choice experiment; see below for more details. The household survey and the choice experiment were developed based on preliminary work in the area and extensive piloting (Poudyal et al., 2016b; Rakotonarivo et al., 2017, 2018). We targeted the interviews at household heads but in many cases other household members assisted with recall (particularly in responding to questions about agriculture and collection of wild harvested products). For the second phase (August 2014 to May 2015), a sub-sample of the households who were interviewed in the first phase were selected using stratified random sampling (based on household size and basic information on landholding from our initial survey) for detailed surveys of agricultural input and output, and off farm income. This allowed us to estimate household income from cash and agricultural production (whether sold or consumed), but excluding wild harvested products for subsistence use (many of these products were rarely marketed, making valuation difficult). These surveys were conducted in sites 1, 2 and 3, with sample size of 40-50 households in each site and involved visits to all land farmed by the household to improve recall. We use these estimates of total household incomes to compare with opportunity cost estimates from the choice experiment. In the third phase (May to July 2016), a follow-up survey was carried out with the 62 households in Site 1 (REDD+ safeguard site) who had received compensation under the World Bank social safeguards in 2014. This involved a contingent valuation exercise to estimate their valuation of the micro-development project that they had received.

RM, OSR, NS, AR and up to three additional assistants - all native Malagasy speakers familiar with the dialect of the region - carried out the interviews. MP (basic Malagasy) and NH and 
222 JPGJ (fluent in conversational Malagasy) attended a subset of interviews. Pictures showing the

223 fieldwork context are shown in the Supplemental Information. The full data set is archived with

224 ReShare, the UK data services online repository (Poudyal et al., 2016a, 2017). All data, along

225 with the code used in our analysis, is available as a GitHub repository

226 (https://github.com/mpoudyal/cepaper). Research permission was granted by the Ministry of

227 Environment, Ecology and Forests (45/14/MEF/SG/DGP/DCB.SAP/SCB).

228

229

230

231

232

233

234

235

236

237

238

239

240

241

242

243

244

245

246

247

248

249

250

251

\section{The choice experiment}

We used a choice experiment to estimate respondents' willingness-to-accept forest conservation in CAZ, specifically the prevention of swidden agriculture in forested areas. Because there are so few cases of choice experiments being properly validated for use in low income country contexts with rural, low literacy populations (Rakotonarivo, Schaafsma \& Hockley, 2016) we invested heavily in refining the choice experiment before rolling it out across the study area. First we explored whether a willingness-to-pay or willingness-to-accept formulation was more suitable. The results showed clearly that willingness-to-accept worked best in this context: it reduced protest responses since it aligned better with local perceptions of (customary) property rights and was more suited to a context where incomes (and therefore ability to pay) are very low (Rakotonarivo et al. 2018). OSR conducted qualitative debriefing interviews to explore the validity of the choice experiment for estimating the opportunity costs of conservation in this context (Rakotonarivo et al., 2017). These were conducted the day after the choice experiment with a sub-sample selected to represent the full range of choice experiment responses $(\mathrm{N}=25$ from 206 respondents in sites 1 and 4) to examine their decision-making processes. .

The choice experiment aimed to assess the net opportunity costs experienced by households prevented from clearing forest for swidden agriculture due to the introduction of conservation restrictions. We asked respondents to choose between a reference level (forest protection is formally lifted and households do not receive any payments or agricultural support) and two experimentally-designed alternatives which varied in our attributes of interest. Choice experiment surveys usually include a status quo option but a status quo option (households' own current "levels" for each attribute) would vary enormously across respondents and elucidating a status quo alternative would require respondents to reveal their current participation in forest clearance (which is a highly sensitive topic). The attributes were: i) A monetary attribute (framed 
252 as the total development assistance the household would receive); ii) Number of annual

253 instalments over which the household would receive the assistance; iii) Support in-kind for

254 improved rice cultivation; and iv) Forest clearance attribute. The forest clearance attribute had

255 three levels: free clearance (forest protection is lifted), permit for one hectare of clearance, and

256 no clearance (strict enforcement of forest conservation). The attributes and levels (Table S1)

257 were informed by the literature, extensive piloting, and three focus group discussions. In

258 particular, levels of the monetary attribute were informed by previous estimates of forest

259 protection opportunity costs in Madagascar and piloting to ensure an adequate level of trading

260 off between this attribute and forest protection (see Rakotonarivo et al., 2017). An example

261 choice card is available in the Supplemental Information (Fig. S6) alongside the full script used

262 in the field (in English and Malagasy).

263 We combined alternative levels of the four attributes in choice tasks using an efficient design

264 that seeks to minimize the standard error of the coefficients to be estimated (Ferrini \& Scarpa,

265 2007). The fractional factorial design was optimized for d-efficiency for the multinomial logit

266 model using Ngene 1.1.1, and based on information on the signs of the parameters obtained from

267 the piloting (Scarpa \& Rose, 2008). The main purpose of this design was to ensure more reliable

268 parameter estimates despite the relatively small sample size that was achievable given the field

269 conditions (Rose \& Bliemer, 2013). The design generated 12 choice tasks which were divided

270 into two blocks; each respondent was presented with six choice tasks. Respondents were

271 randomly assigned to one of the two blocks in the experiment.

\section{Research ethics}

273 Bangor University College of Natural Sciences ethics committee approved this study (on

274 29/10/2013), and all members of the survey team received ethics training (covering

275 confidentiality and informed consent). When we introduced the project we gave selected

276 households a leaflet explaining the aims of the research with photos and names of the research

277 team and contact details. We explained that participation in the research was voluntary, that they

278 could leave at any time, and that no information that could identify them would be shared with

279 others. We gave a small gift of useful items such as cups, pens, school books, or cigarette

280 lighters to a total value of 3000 ariary (approximately US\$1) after interviews in phases one and

281 three as a gesture of appreciation for their time. The detailed surveys in phase two took a whole 
282 day and required the household head to take us around his land holdings, therefore we paid

283 respondents the local daily wage rate of 5000 ariary (approximately US\$1.85).

\section{Data analysis}

285 Characterising poverty: Poverty is a multidimensional concept (Alkire et al., 2015). We

286

287

288

289

290

291

292

293

294

295

296

297

298

299

300

301

302

303

304

305

306

307

308

309

therefore used a range of poverty indicators selected for the rural Malagasy context (see Table 2).

The indicators of poverty were analyzed using a principal component analysis (PCA) in the R psych package (Revelle, 2017) based on polychoric and polyserial correlations estimated in the $\mathrm{R}$ polycor package (Fox, 2010). Input variables to the correlation matrix were measures of household food security, house size, house quality, access to lighting, and education level of the household head (see Table 2).

Converting ariary to US\$: We used the World Bank's Global Economic Monitor database on historic exchange rates to get US\$ - Malagasy ariary median exchange rate for the period of data collection between July 2014 and June 2015 (World Bank, 2017a). The median exchange rate thus obtained is 2,702 MGA for one US\$, which is used in all our analyses and in conversion of local currency into US\$. We use the seasonally adjusted consumer price index data from the same source to adjust any local currency values outside of the above period before converting to US\$ figures for comparison.

Modelling choice experiment: The discrete choice data was analyzed with a mixed logit model using the R gmnl package (Sarrias \& Daziano, 2015). The mixed logit approach introduces preference heterogeneity by 'individualizing' preferences; each respondent has a possibly unique set of preference parameters (Train 2003). As it is not practical to estimate the parameter vector governing the behavior of individual respondents, preference parameters are instead defined as random draws from a joint distribution and mixed logit models estimate a distribution of these parameters from the full sample. With the exception of the fixed payment parameter all parameters are specified as random and given a normal distribution (truncated normal in the case of the opportunity cost parameter). The opportunity cost estimates were derived from the marginal rate of substitution between the forest clearance attribute and the monetary attribute. They are calculated as follows: 
310 Opportunity cost estimates $=\frac{\beta_{i}}{\beta_{\text {price }}}$

311 Where $\beta_{i}$ are the attribute coefficients of strict protection, and $\beta_{\text {price }}$ are the price coefficients.

312 Standard errors on the cost estimates were estimated from the mean and covariance matrix using 313 the delta method.

314 Comparing the magnitude of opportunity costs with local incomes: We estimated household

315 income for a subset of 102 households using the detailed surveys in phase 2 (see Supplemental

316 Information). We annualized our estimates of opportunity cost using a 60 year time horizon and

317 a range of discount rates of $0.001-5 \%$. While selecting an appropriate time horizon and discount

318 rates for annualizing NPV estimates is difficult, we argue that these choices are well supported

319 and also conservative (as long time horizons and low discount rates result in lower annual costs).

320 These calculations allowed us to present annualized opportunity costs as a percentage of the total

321 household income.

322

323

324

325

326

327

328

329

330

331

332

333

334

335

336

337

Estimating the value of the compensation received by compensated households: We used a random card sort exercise (Shackley \& Dixon, 2014) to help respondents estimate the value of the compensation provided by trading it off against seven levels of hypothetical cash payment. This elicited upper and lower bounds for respondents' willingness to accept cash in place of the compensation. We then asked a single open ended contingent valuation question to elicit a single willingness to accept value (which always lay within the bounds identified by the random card sort, see supplementary information). This valuation was conducted ex-post to value the compensation as it had actually been delivered. Respondents were invited to take into consideration what they knew about how well the compensation project had worked and decide whether, if offered the opportunity to choose, they would choose the project or a cash sum. Debriefing questions found that 57 of 62 respondents felt the exercise "definitely showed" the true value of the project to them, suggesting this method was successful.

Estimating the total number of households bearing significant opportunity costs in CAZ: The median distance of our surveyed households from the protected area boundary was $2 \mathrm{~km}$. Therefore we drew a conservative $2 \mathrm{~km}$ buffer around the outer boundary of the CAZ protected area (excluding other parks and reserves) to define the area for which we have information on local 
338 opportunity costs (Supplemental Information Fig. S4). We ran the EcoEngine population algorithm 339 in WaterWorld (Mulligan, 2013) using two spatial population datasets (1) Fokontany-level 340 (Fkt2010) data (provided by the national statistics agency INSTAT Madagascar), and (2) Landscan 3412007 (LS07) dataset (Bright et al., 2008) and masked to the shapefile of CAZ with the $2 \mathrm{~km}$ buffer 342 to get population distribution within the area of interest (Supplemental Information Fig. S4). We 343 compared the population distribution from these two datasets to the census data we collected from 344 our study sites (Supplemental Information Fig. S5). The LS07 population estimates were much 345 more representative of our census estimates. Using this data we estimated the population in and 346 around the CAZ new protected area was 49,183 people at $1 \mathrm{~km}$ resolution grid, equating to 9,837 347 households with a median household size of five (see Table 2). We then multiplied this figure by 348 our estimated proportion of households in the CAZ sites (site 1 and site 2) with NPV of opportunity 349 costs higher than a range of thresholds to estimate the total number of households with significant 350 opportunity costs for the whole of CAZ.

351

352

353

354

355

Estimating the global value of conservation of the CAZ: The CAZ protected area is projected to avoid the release of appropriately one million tonnes of $\mathrm{CO}_{2}$ per year for 10 years (Rainforest Alliance, 2013). We used this figure, and the average social cost per tonne of $\mathrm{CO}_{2}$ for 2015 at $5 \%$ discount rate, US\$ 11 (US Government, 2016), to estimate the social value of the CAZ protected area in terms of its contribution to climate mitigation as approximately US $\$ 110,000,000$.

\section{Results}

\section{Livelihoods of people in the CAZ}

People living around the CAZ forest are extremely poor (Table 2). Food security is low: the median number of months for which families have enough to eat was just seven. Household assets are low: the median household owns just 0.05 Tropical Livestock Units (equivalent to five chickens). The vast majority of people live in small, poor quality houses of just one or two rooms made of local materials and have insufficient access to light (Table 2). Most household heads are illiterate or have less than two years of schooling. Ninety percent of people in the study area are dependent on swidden agriculture for their livelihood (Table 2). Twenty percent of respondents have obtained land directly from clearing the forest (others have bought or inherited cleared land), although this varies between sites (Supplemental Information Fig. S1). Only 37\% of 
367 households have access to irrigated rice fields (Table 2). Principal component analysis (PCA) of

368 seven measures of wealth resulted in two axes which explained $45 \%$ of the variation and

369

370

371

372

373

374

375

376

377

378

379

380

381

382

383

384

385

386

387

388

389

390

391

392

393

394

revealed no systematic differences between our four sites in terms of wealth (Fig. 2). These two axes were used as covariates in analyzing the choice experiment.

\section{The magnitude and distribution of local opportunity costs of preventing swidden} agriculture

The median net present value of the opportunity cost across households in all sites is US $\$ 2,375$. (Fig. 3-a, see Supplemental Information Table S2 for the coefficients from the choice experiment). The opportunity cost per household varies between sites. Interestingly, the site-level effect on the net opportunity costs estimate was greater (more negative) for the site that did not receive compensation than the site which was assessed by environmental and social safeguard assessment (World Bank, 2012) as eligible to receive compensation and where some households did receive compensation (Fig. 3-b). Opportunity cost estimates from the sites adjoining longestablished protected areas (where communities have experience of conservation restrictions) are higher on average than sites adjoining CAZ (where conservation restrictions are new) (Fig. 3-a).

This may reflect the effect of experience; i.e. they are better able to estimate the costs of conservation as have experienced the challenge of switching to livelihoods not based on swidden agriculture (Rakotonarivo et al., 2017).

Households further away from the forest frontier and with more educated household heads expected lower opportunity costs. There was no effect of either wealth axis on net opportunity costs (Fig. 3-b), implying a higher proportional burden for poorer households.

Using detailed agricultural surveys we estimated total annual household incomes for a subset of households at sites 1, 2 and 3 (Fig. 4). For a range of realistic discount rates $(0.001 \%, 2.5 \%$ and $5 \%$ ) over a 60 year timeframe, we estimated annualized opportunity costs, which for median NPV were respectively US \$40, \$77 and \$125 (Supplemental Information). It is important to note, however, that median income households do not necessarily bear median opportunity costs. Our estimates of annualized opportunity costs represented around $27 \%$ to $84 \%$ of the median total annual household income in these three sites for median income households (Fig 4). This 
395 proportion is greater for the poorest households compared with those who are less poor; this

396 finding was consistent across the range of discount rates (Fig. 4).

397 We estimated the number of households who might be considered eligible for compensation

398

399

400

401

402

403

404

405

406

407

408

409

410

411

412

413

414

415

416

417

418

419

420

421

422 using three thresholds (net present value of opportunity cost being greater than twice, three times and four times median annual income). This results in estimates of 6,274; 5,922 and 5,521 households in and around the new protected area which we argue should be considered eligible to receive compensation (Fig. 5-a).

We estimate that the present value of opportunity costs borne by local people due to the conservation restrictions imposed by the CAZ REDD+ pilot project are between 13 and 15 million US\$ (5,521-6,274 households multiplied by the estimated median opportunity cost of US\$2,375).

\section{The magnitude and distribution of the compensation received}

The environmental and social safeguard assessment of the CAZ new protected area initially identified 2,500 households as negatively affected by the protected area (World Bank, 2012). Using our conservative estimate of the number of households bearing NPV of opportunity costs higher than 2-4 times their median annual incomes (see above), we suggest that there are between 3,020-3,770 households unidentified for compensation (between 15,100 and 18,850 people). Therefore, even with our most conservative estimate of the number of households eligible for compensation, less than $50 \%$ of these were identified by the World Bank process (Supplemental Information). According to the final project implementation report of the World Bank regarding the implementation of safeguards around CAZ, 1,012 of the 2,500 households had yet to receive compensation by the end of 2015 (World Bank 2016) so even this conservative number is likely to be an underestimate of the proportion of eligible households who have not received compensation.

The feasibility plan for the implementation of the social safeguard scheme surrounding CAZ (MEEF/SAPM/CI, 2013) suggests that approximately US\$ 100-170 would be spent on each household eligible for compensation, excluding transaction costs. For the households who received this compensation the projects went ahead as planned (with some adaptations - for 
423

424

425

426

427

428

429

430

431

432

433

434

435

436

437

438

439

440

441

442

443

444

445

446

447

448

449

450

451

example, in site 1, technical farming support for irrigated rice was replaced with support for rainfed beans). Assuming that the total budgeted amount for direct compensation per household was spent, the amount spent per household on compensation was therefore within the range of our estimate of annual opportunity costs, however, it is important to note that these are one-off projects, with no further support budgeted for subsequent years.

Using a contingent valuation exercise two years after project delivery with all 62 households who received the compensation in site 1, we found that on average these households valued the projects that they had received at a net present value of US\$ 79. This is of the same order of magnitude as the annual opportunity costs estimated by the safeguard assessment (\$120) (World Bank, 2012) but considerably less than the net present value of the opportunity cost (median = $\$ 2,375$ ) (Fig. 5-b). For the majority of households studied, these compensation projects covered less than $5 \%$ of their opportunity costs while only a few households with very low opportunity costs were better compensated (maximum $\sim 45 \%$ ) (Supplemental Information Fig. S2). We therefore conclude that none of the households were fully compensated (Fig. 5-a).

The total projected spend on compensating local communities was approximately US $\$ 250,000$ $\$ 425,000$ ( $\$ 100$ or $\$ 170$ multiplied by the 2,500 households who were initially identified for compensation). However, this is likely to be a significant overestimate of the actual compensation spend, since by the end of the project at least 1012 remained uncompensated and some households from the initial list had been dropped for other reasons such as relocation or migration from CAZ (World Bank 2016). Yet even this projected spend is two orders of magnitude less than our estimate of the total local opportunity cost. The amount of compensation spent per household is much lower than the carbon value that the REDD+ project in CAZ is expected to deliver during the first 10 years. Our conservative value for the carbon emissions which could be avoided over the life of the project (US\$110,000,000, see above) represents approximately US\$11,000 per household for every household within CAZ or $2 \mathrm{~km}$ of its borders (Fig. 5-b).

\section{Discussion}

We have demonstrated that some of the poorest people in one of the poorest countries in the world are bearing very high opportunity costs due to conservation restrictions. These costs, when 
452 annualized, are a significant proportion of annual incomes. This is realistic when we consider

453 that these costs are incurred over many years and indeed several generations. Despite the

454 common narrative among conservationists that benefits from swidden agriculture are very short-

455 lived as soil fertility is rapidly lost, and therefore any costs of conservation can also only be

456 short-lived, the evidence does not support this (Brand \& Pfund, 1998; Nielsen, Mertz \& Noweg,

457 2006; Mertz et al., 2009; Rerkasem et al., 2009; Ziegler et al., 2009). In our own study sites,

458 many families have been farming the same land through swidden cultivation for well over 100

459 years. Studies on traditional swidden agricultural systems in Madagascar and in other parts of the

460 world generally agree that long-fallow swidden systems can be sustainable in the long term

461 (Dove, 1983; Jarosz, 1996; Kerkhoff \& Sharma, 2006; Erni, 2015) and can compete with more

462 intensive farming systems in terms of returns to labor (Dove, 1983; Oxby, 1985; Nielsen, Mertz

$463 \&$ Noweg, 2006). Swidden agriculture can also be of lower risk than alternatives and therefore be

464 particularly vital to the poorest who have few alternatives (Nielsen et al. 2006, Scales 2014).

465 Extensive qualitative debriefing shows that respondents did consider the varied and multiple

466 influences and made meaningful trade-offs in the choice experiments (Rakotonarivo et al., 2017).

467 Qualitative evidence (Rakotonarivo, 2016) shows that people took the long view when

468 considering their responses, and also that some respondents expected cultural losses as well as

469 more tangible costs, from enforced cessation of swidden agriculture. When annualized, our

470 estimates of opportunity cost are close to the official estimate in the CAZ environmental and

471 social safeguard document (World Bank, 2012) which used a very different approach. They are

472 also comparable to an estimate of the annual opportunity cost incurred by rural Ugandan farmers

473 of forgoing agriculture on forestlands (US\$ 354/household/year; Bush et al., 2013). Finally, a

474 number of us have met Malagasy farmers who have been jailed (a very serious punishment in a

475 country where prison conditions are very severe; Roth, 2006) for clearing forest; demonstrating

476 how strongly people rely on this activity and that conservation restrictions have a serious local

477 cost.

478 Why do local costs of conservation matter?

479 Excluding local people from protected areas, or restricting their livelihood options within those

480 areas without compensation has a number of problems. First, it ignores the rights of local

481 communities to manage their land and natural resources; an environmentally unjust situation 
482 (Martin, McGuire \& Sullivan, 2013; Mcdermott, Mahanty \& Schreckenberg, 2013) and results in 483 some of the world's poorest people bearing costs to supply global environmental benefits.

484 Second, there can be implications for the sustainability of the conservation intervention itself as

485

486

487

488

489

490

491

492

493

494

495

496

497

498

499

500

501

502

503

504

505

506

507

508

509 uncompensated losses can result in antagonism or even retribution (Naughton-Treves, Holland \& Brandon, 2005). Sustainable management of protected areas in countries like Madagascar, with political instability, weak governance and poor infrastructure, depends in part on the goodwill of local communities (Rasolofoson, Nielsen \& Jones, 2018). Illicit mining and logging have caused significant degradation in many of Madagascar's protected areas in recent years (Allnutt, Asner \& Golden, 2013; Rakotomanana, Jenkins \& Ratsimbazafy, 2013; Schwitzer et al., 2014). While local communities cannot prevent these incursions by themselves, their cooperation is vital to the success of conservation (Fritz-Vietta et al., 2011), yet this cooperation is unlikely if protected areas bring only costs.

\section{What about the local benefits?}

The majority of people in eastern Madagascar collect a wide range of wild-harvested products for subsistence use and trade (including building materials, fibers, famine foods Ratsimbazafy et al., 2011), and may experience other benefits of maintaining standing forest. Our choice experiment was designed to estimate net costs, taking account of all influences (positive or negative) on a respondent's utility and qualitative debriefing suggests that respondents did consider both costs and benefits of conservation when formulating responses. Our method cannot distinguish between those who have a net positive utility for forest conservation and those who experience no opportunity cost (i.e., are neutral). A small number (less than 15\%) of responding households have zero net costs, perhaps because they live relatively far from the forest, are not dependent on agriculture or are too old to clear new lands. Some of these households may derive net positive benefits from forest conservation (due to cultural reasons or because they perceive forest to be important for providing clean water or air). We are not in a position to estimate the magnitude of utility these people might get from forest conservation, but this does not affect our estimates of the number of households that expect net-negative costs or the magnitude of those costs. 


\section{Is compensation reaching the right people?}

511 We conservatively estimate that less than $50 \%$ of those who should have been eligible for

512 compensation were identified as eligible. In one of our study sites (site 2), no compensation was

513 distributed at all, but our estimates show that opportunity costs at this site are at least comparable

514 to those in the site where compensation was distributed (site 1). At the site level, previous work

515 by our team has demonstrated that in site 1 (where compensation was distributed) those reached

516 were not necessarily the most deserving but were those with better socio-economic and political

517 status locally, and easier to access geographically (Poudyal et al., 2016b). Furthermore, while

518 2,500 households were initially identified to receive compensation (World Bank, 2012), by the

519 end of 2015 the World Bank stated that 1,012 of these households had yet to receive

520 compensation and some others (no number provided) had been excluded from the list due to

521 migration, or unwillingness to take part in the compensation programme (World Bank, 2016).

\section{Is compensation sufficient?}

523 The average one-off spend on providing compensation to each household who received it was

524 similar to the average annual opportunity cost of swidden agriculture estimated by the CAZ

525 environmental and social safeguard document (World Bank, 2012).It is highly unlikely that

526 annual benefits can be generated that are of similar magnitude to the initial investment, and our

527 valuation of the compensation received (two years after it was distributed) confirmed that local

528 people valued the projects, on average, at slightly less than they cost to deliver. The costs of

529 conservation are likely to be felt over decades therefore even those people who received

530 compensation are under-compensated relative to the costs they will incur. The number of

531 households in the CAZ for whom the safeguard compensation fully compensated for their

532 opportunity costs is therefore zero.

533 Sometime in 2018, the World Bank will launch its new Environmental and Social Framework;

534 the result of four years of consultation on the existing environmental and social safeguard

535 policies (World Bank, 2017b). While the aspirations for what the social safeguards seek to

536 achieve with respect to economically displaced persons remain clear and strong, some experts

537 have raised concern that oversight will be weakened under the new framework as responsibility

538 to ensure safeguards are met is shifting from the lender (the Bank) to the borrower (Passoni, 
539 Rosenbaum \& Vermunt, 2018). Given our work shows that even with existing levels of

540 oversight, projected affected persons are under-compensated, this is concerning.

541 Can forest conservation in low-income countries be achieved without the poorest bearing 542 the costs?

543 As Madagascar develops, it can be expected that many people will choose to move away from

544 swidden agriculture towards more intensive agricultural systems and to livelihoods not based 545 directly on the land (Jones et al., 2018); a transition which has been seen in other parts of the 546 world (Cramb et al., 2009; Schmidt-Vogt et al., 2009). The question is, how can the forests be 547 protected during that transition and while Madagascar's economic development continues to be 548 slow and beset by regular political crises?

549 Although complex, we argue that, resolving land tenure in forested areas (including recognizing 550 and respecting customary rights) is vital if effective conservation is to be achieved without poor 551 local people bearing the cost. Indeed, resolving issues surrounding tenure of forested land 552 (particularly mature tree fallows) could also benefit local people and forest conservation for two 553 reasons. First, if local peoples' rights over forest are legally recognized, it puts them in a stronger 554 position to argue for effective compensation, reduces the possibility of a resource rush (Sunderlin 555 et al., 2014; Rakotonarivo et al., 2018), and would ultimately reduce the transaction costs of 556 negotiating fair compensation (Pham et al., 2013). Second, by undermining customary tenure, 557 weakly enforced state ownership can increase deforestation rather than reduce it (Horning, 558 2005). For example, if local people cannot exclude others from clearing 'their' tree fallows, this 559 provides perverse incentives for such land to be cleared more often than would be optimum for 560 the customary owner; resulting in shorter fallow cycles and land degradation.

561 There has been recent progress in Madagascar in formalizing tenure, with the establishment of 562 land tenure offices at the commune level (although the process of issuing land certificates is still 563 slow and coverage of land offices is patchy; Burnod et al., 2014; Widman, 2014). Unfortunately, 564 there are two significant challenges to resolving the tenure of farmers on Madagascar's forest 565 frontier. First, although mature tree fallows are locally considered part of agricultural land, the 566 current forest code does not allow formal tenure to be granted over such land as it is considered 567 to be state land (Jones et al., 2018). Second, under the current tenure laws (Laws 2005-019 and 
568 2006-031), those living within the border of protected areas, i.e. many of those considered in this 569 study, are not eligible to formalize their tenure.

570 We estimate that the total local opportunity costs of conservation restrictions in the CAZ 571 protected area are US\$ 13-15 million, while the total amount projected to be spent on 572 compensating households was less than US\$ 425,000. This suggests that substantially greater investment in compensation is needed to ensure that local opportunity costs are compensated; greatly increasing the implementation costs of such projects. Because opportunity costs will be incurred over a long time period, this compensation could also be spread over several decades (although this is no excuse for complacency: costs will be felt by some households from the first years of protected area establishment). Global conservation efforts are already underfunded by at least an order of magnitude (McCarthy et al., 2012; Waldron et al., 2013). However, when put in the context of the global value of ecosystem services lost due to land use change (Costanza et al., 2014) and the fact that a conservative estimate of the value of $\mathrm{CO}_{2}$ emissions avoided by protecting the CAZ is over US\$ 110 million over 10 years, the figures involved are relatively small. They would, however, require a major change in resource allocation to provide sufficient funds to compensate for opportunity costs (and cover the significant transaction costs associated with safeguard compensation programs; Mackinnon et al., 2017).

What are the implications of this work for the implementation of REDD+ social safeguards?

Following the 2015 Paris climate agreement, REDD+ was formally confirmed as part of the global tool kit for mitigating climate change. The UNFCC Cancun agreement (UNFCCC, 2011) had already laid out the safeguards that REDD+ programs must follow to avoid negative environmental or social impacts (Decision 1/CP.16). The Cancun safeguards are very different from the World Bank social safeguards and do not explicitly refer to compensation for affected persons, but they do require that knowledge and rights of local communities are respected, that there is effective local participation in REDD design and implementation, and social co-benefits are promoted. Madagascar is currently in the process of finalizing its national REDD+ strategy, which includes developing social and environmental safeguards in line with the Cancun commitments. We suggest that there are important lessons from our work to inform that strategy; 
597 especially given the paucity of published work exploring the effectiveness of REDD+ social 598 safeguards (Duchelle et al., 2017). These are: there are significant and long lasting costs to local 599 people from restrictions on clearing forest land for agriculture, these should be addressed both 600 for environmental justice reasons but also to improve the sustainability of forest conservation 601 and this will require significant investment. Reaching the poorest and most marginalized is 602 difficult and deserves special attention. Finally, rigorous and independent monitoring will be 603 needed to ensure that any safeguards program achieves its stated objectives on the ground.

\section{Conclusions}

605 Conservation as a movement recognizes that sustainable management of natural resources cannot be achieved without considering local people. This has resulted in very positive commitments to avoid negative impacts of conservation restrictions on local communities. However, there has been little formal scrutiny of the extent to which these commitments are delivered upon. We evaluate an example of a new protected area that has been established with commitments to avoid negative impacts on local people. Unfortunately we show that the local people, some of the poorest in the world, have lost out as a result of the protected area establishment, and that compensation provided to mitigate these costs has been inadequate. Too little has been received by too few and it has not reached those most in need. These are challenging results to present and we do so cautiously. We recognize that the individuals and organizations involved are often doing their best in very challenging circumstances. However, we want to draw global attention to the fact that having policies in place to protect local people from the costs of conservation is not sufficient: they must be accompanied by adequate investment, over long periods. There is no straightforward solution and effective compensation will be expensive. However we argue that ignoring the issue of local costs is both unjust (and therefore immoral) and also unsustainable. Real change and substantial new investment is needed.

\section{Acknowledgments}

622 We thank local leaders and all the people interviewed for participating in this research. We also 623 thank the Malagasy government for research permission. We thank D.T. Rafanomezantsoa, R. 624 Heriniaina, T. Razafimandimby, and T. Brodin for help with the fieldwork and J. Jacobsen for 625 support with the choice experiment. We thank Conservation International Madagascar, K. 
626 Schreckenberg, P. Ranjatson and the wider p4ges team for useful discussion. M. Mulligan helped

627 with our population estimates. The World Bank Madagascar shared information on the

628 safeguarding process in CAZ. We thank the Malagasy government's national coordination office

629 of REDD+ (particularly M. Andriamanjato) for discussion about the emerging social safeguard

630 strategy for REDD+.

631 References

632 Adams VM., Pressey RL., Naidoo R. 2010. Opportunity costs: Who really pays for conservation?

633 Biological Conservation 143:439-448. DOI: http://dx.doi.org/10.1016/j.biocon.2009.11.011.

634 Agrawal A., Redford K. 2009. Conservation and displacement: An overview. Conservation and 635 Society 7:1-10. DOI: 10.4103/0972-4923.54790.

636

637

638

639

640

641

642

643

644

645

646

647

648

649

650

651

Alkire S., Jindra C., Robles AG., Seth S., Vaz A. 2015. Global multidimensional poverty index. Oxford Poverty \& Human Development Initiative. DOI: www.ophi.org.uk.

Allnutt TF., Asner GP., Golden CD. 2013. Mapping recent deforestation and forest disturbance in northeastern Madagascar. Tropical Conservation Science 6:1-15.

Anonymous. 2013. The Equator Principles III - A financial industry benchmark for determining, assessing and managing environmental and social risk in projects. The Equator Principles Association.

Antona M., Bienabe EM., Salles J-M., Pichard G., Aubert S., Ratsimbarison R. 2004. Rights transfers in Madagascar biodiversity policies: achievements and significance. Environment and Development Economics 9:825-847. DOI: 10.1017/S1355770X04001640.

Baccini A., Goetz SJ., Walker WS., Laporte NT., Sun M., Sulla-Menashe D., Hackler J., Beck PSA., Dubayah R., Friedl MA., Samanta S., Houghton RA. 2012. Estimated carbon dioxide emissions from tropical deforestation improved by carbon-density maps. Nature Climate Change 2:182-185. DOI: 10.1038/nclimate1354.

Balmford A., Whitten T. 2003. Who should pay for tropical conservation, and how could the costs be met? Oryx 37:238-250. DOI: 10.1017/S0030605303000413. 
652 Bidaud, C., Schreckenberg, K. \& Jones, JPG. 2018. The local costs of biodiversity offsets: 653 comparing standards, policy and practice. Land Use Policy. 77: 43-50. DOI: 10.1016/j.landusepol.2018.05.003

655

656

657

658

659

660

661

662

663

664

665

666

667

668

669

670

671

672

673

674

675

676

677

Brand J., Pfund JL. 1998. Site-and watershed-level assessment of nutrient dynamics under shifting cultivation in eastern Madagascar. Agriculture, Ecosystems \& Environment 71:169-183. DOI: http://dx.doi.org/10.1016/S0167-8809(98)00139-X.

Bright EA., Coleman PR., King AL., Rose AN. 2008. LandScan 2007. DOI: http://www.ornl.gov/landscan/.

Burnod P., Andrianirina-Ratsialonana R., Ravelomanantsoa Z. 2014. Land certification in Madagascar: formalizing (f)or securing? World Bank Conference on Land and Poverty:15. DOI: http://agritrop.cirad.fr/574062/1/document_574062.pdf.

Bush G., Hanley N., Moro M., Rondeau D. 2013. Measuring the Local Costs of Conservation: A Provision Point Mechanism for Eliciting Willingness to Accept Compensation. Land Economics 89:490-513.

Costanza R., de Groot R., Sutton P., van der Ploeg S., Anderson SJ., Kubiszewski I., Farber S., Turner RK. 2014. Changes in the global value of ecosystem services. Global Environmental Change: Human and Policy Dimensions 26:152-158. DOI: http://dx.doi.org/10.1016/j.gloenvcha.2014.04.002.

Cramb RA., Colfer CJP., Dressler W., Laungaramsri P., Le QT., Mulyoutami E., Peluso NL., Wadley RL. 2009. Swidden transformations and rural livelihoods in Southeast Asia. Human Ecology 37:323-346. DOI: 10.1007/s10745-009-9241-6.

Dove MR. 1983. Theories of swidden agriculture, and the political economy of ignorance. Agroforestry Systems 1:85-99. DOI: 10.1007/bf00596351.

Duchelle AE., de Sassi C., Jagger P., Cromberg M., Larson AM., Sunderlin WD., Atmadja SS., Resosudarmo IAP., Pratama CD. 2017. Balancing carrots and sticks in REDD+: implications for social safeguards. Ecology and Society 22:art2. DOI: 10.5751/ES-09334-220302. 
678 Erni C. 2015. Shifting cultivation, livelihood and food security: New and old challenges for 679 indigenous peoples in Asia.

680

681

682

683

684

685

686

687

688

689

690

691

692

693

694

695

696

697

698

699

700

701

702

703

Ferrini S., Scarpa R. 2007. Designs with a priori information for nonmarket valuation with choice experiments: A Monte Carlo study. Journal of Environmental Economics and Management 53:342-363. DOI: http://dx.doi.org/10.1016/j.jeem.2006.10.007.

Fisher B., Edwards DP., Giam X., Wilcove DS. 2011. The high costs of conserving Southeast Asia's lowland rainforests. Frontiers in Ecology and the Environment 9:329-334. DOI: $10.1890 / 100079$.

Fox J. 2010. polycor: Polychoric and polyserial correlations. :R package.

Fritz-Vietta NVM., Ferguson HB., Stoll-Kleemann S., Ganzhorn JU. 2011. Conservation in a biodiversity hotspot: insights from cultural and community perspectives in Madagascar. In: Zachos FE, Habel JC eds. Biodiversity Hotspots: Distribution and Protection of Conservation Priority Areas. Berlin, Heidelberg: Springer Berlin Heidelberg, 209-233. DOI: 10.1007/9783-642-20992-5_12.

Gardner CJ., Nicoll ME., Mbohoahy T., Oleson KLL., Ratsifandrihamanana AN., Ratsirarson J., René de Roland L-A., Virah-Sawmy M., Zafindrasilivonona B., Davies ZG. 2013. Protected areas for conservation and poverty alleviation: experiences from Madagascar. Journal of Applied Ecology 50:1289-1294. DOI: 10.1111/1365-2664.12164.

Green JMH., Fisher B., Green RE., Makero J., Platts PJ., Robert N., Schaafsma M., Turner RK., Balmford A. 2018. Local costs of conservation exceed those borne by the global majority. Global Ecology and Conservation 14:e00385. DOI: 10.1016/j.gecco.2018.e00385.

Gupta J., Vegelin C. 2016. Sustainable development goals and inclusive development. International Environmental Agreements: Politics, Law and Economics 16:433-448. DOI: 10.1007/s10784-016-9323-z.

Hall A. 2007. Social policies in the World Bank: Paradigms and challenges. Global Social Policy 7:151-175. DOI: 10.1177/1468018107078160. 
704 705

706

707

708

709

710

711

712

713

714

715

716

717

718

719

720

721

722

723

724

725

726

727

728

729

Hanley N., Wright RE., Adamowicz V. 1998. Using choice experiments to value the environment. Environmental and Resource Economics 11:413-428. DOI: 10.1023/a:1008287310583.

Harvey CA., Rakotobe ZL., Rao NS., Dave R., Razafimahatratra H., Rabarijohn RH., Rajaofara H., MacKinnon JL. 2014. Extreme vulnerability of smallholder farmers to agricultural risks and climate change in Madagascar. Philosophical Transactions of the Royal Society of London B: Biological Sciences 369.

Hausman J. 2012. Contingent valuation: From dubious to hopeless. Journal of Economic Perspectives 26:43-56. DOI: doi: 10.1257/jep.26.4.43.

Horning NR. 2005. The cost of ignoring rules: Forest conservation and rural livelihood outcomes in Madagascar. Forests, Trees and Livelihoods 15:149-166. DOI: 10.1080/14728028.2005.9752517.

IFC. 2012. Performance standards on environmental and social sustainability. International Finance Corporation (IFC).

Jarosz L. 1996. Defining deforestation in Madagascar. In: Peet R, Watts M eds. Liberation ecologies: Environment, development, social movements. London: Routledge, 148-164.

Jones JPG., Mandimbiniaina R., Kelly R., Ranjatson P., Rakotojoelina B., Schreckenberg K., Poudyal M. 2018. Human migration to the forest frontier: Implications for land use change and conservation management. Geo: Geography and Environment 5:e00050. DOI: 10.1002/geo2.50.

Kaczan D., Swallow BM., Adamowicz WL. 2013. Designing a payments for ecosystem services (PES) program to reduce deforestation in Tanzania: An assessment of payment approaches. Ecological Economics 95:20-30. DOI: http://dx.doi.org/10.1016/j.ecolecon.2013.07.011.

Kenter JO., Hyde T., Christie M., Fazey I. 2011. The importance of deliberation in valuing ecosystem services in developing countries-Evidence from the Solomon Islands. Global Environmental Change: Human and Policy Dimensions 21:505-521. DOI: http://dx.doi.org/10.1016/j.gloenvcha.2011.01.001. 
730 Kerkhoff E., Sharma E. 2006. Debating shifting cultivation in the Eastern Himalayas: Farmers' 731 innovations as lessons for policy. Kathmandu: International Centre for Integrated Mountain 732 Development (ICIMOD).

733 734

Lawrence D., Vandecar K. 2015. Effects of tropical deforestation on climate and agriculture. Nature Climate Change 5:27-36. DOI: 10.1038/nclimate2430http://www.nature.com/nclimate/journal/v5/n1/abs/nclimate2430.htm 1\#supplementary-information.

Lockwood M., Quintela CE. 2006. Chapter 12: Finance and Economics. In: Lockwood M, Worboys G, Kothari A eds. Managing Protected Areas: A Global Guide. London: Earthscan,.

Louviere JJ., Hensher DA., Swait JD. 2000. Stated Choice Methods: Analysis and Applications. Cambridge: Cambridge University Press.

Louviere JJ., Pihlens D., Carson R. 2011. Design of discrete choice experiments: a discussion of issues that matter in future applied research. Journal of Choice Modelling 4:1-8. DOI: http://dx.doi.org/10.1016/S1755-5345(13)70016-2.

Mackinnon JL., Andriamaro L., Rambelson A., Razafindrazakasoa M., Harvey CA. 2017. Costs of delivery approaches for providing livelihood projects to local communities as part of REDD+ programmes: An analysis from Madagascar. Environmental Conservation:1-9. DOI: 10.1017/S0376892917000571.

Martin A., McGuire S., Sullivan S. 2013. Global environmental justice and biodiversity conservation. The Geographical Journal 179:122-131. DOI: 10.1111/geoj.12018.

Martinez C., Mueller M. 2015. The SDGs: Oppurtunities for Conservation. Environmental Policy and Law 456.

McCarthy DP., Donald PF., Scharlemann JPW., Buchanan GM., Balmford A., Green JMH., Bennun LA., Burgess ND., Fishpool LDC., Garnett ST., Leonard DL., Maloney RF., Morling P., Schaefer HM., Symes A., Wiedenfeld DA., Butchart SHM. 2012. Financial costs of meeting global biodiversity conservation targets: current spending and unmet needs. Science 338:946-949. DOI: 10.1126/science.1229803. 
757 Mcdermott M., Mahanty S., Schreckenberg K. 2013. Examining equity: A multidimensional

758

759

760

761

762

763

764

765

766

767

768

769

770

771

772

773

774

775

776

777

778

779

780

781

782 framework for assessing equity in payments for ecosystem services. Environmental Science and Policy 33:416-427. DOI: 10.1016/j.envsci.2012.10.006.

MEEF/SAPM/CI. 2013. Etude de faisabilité des sous-projets de compensation des personnes affectées par le projet, nouvelle aire protégée du Corridor Ankeniheny-Zahamena (NAP $C A Z)$. Madagascar: Programme Environmental III.

Mertz O., Padoch C., Fox J., Cramb RA., Leisz SJ., Lam NT., Vien TD. 2009. Swidden change in Southeast Asia: understanding causes and consequences. Human Ecology 37:259-264. DOI: $10.1007 / \mathrm{s} 10745-009-9245-2$.

Millennium Ecosystem Assessment. 2005. Ecosystems and Human Well-being: Synthesis. Washington, DC.

Mittermeier RA., Myers N., Thomsen JB., Da Fonseca GAB., Olivieri S. 1998. Biodiversity hotspots and major tropical wilderness areas: Approaches to setting conservation priorities. Conservation Biology 12:516-520. DOI: 10.1046/j.1523-1739.1998.012003516.x.

Moros L., Velez MA., Corbera E. 2017. Payments for Ecosystem Services and Motivational Crowding in Colombia's Amazon Piedmont. Ecological Economics. DOI: 10.1016/J.ECOLECON.2017.11.032.

Mulligan M. 2013. WaterWorld: a self-parameterising, physically based model for application in data-poor but problem-rich environments globally. Hydrology Research 44:748-769. DOI: 10.2166/nh.2012.217.

Muttenzer F. 2006. The folk conceptualisation of property and forest-related going concerns in Madagascar. In: Benda-Beckmann F von, Benda-Beckmann K von, Wiber MG eds. Changing Properties of Property. New York: Berghahn Publishers, 269-292.

Naughton-Treves L., Holland MB., Brandon K. 2005. The role of protected areas in conserving biodiversity and sustaining local livelihoods. Annual Review of Environment and Resources 30:219-252. DOI: doi:10.1146/annurev.energy.30.050504.164507. 
783 Nielsen MR., Jacobsen JB., Thorsen BJ. 2014. Factors determining the choice of hunting and trading bushmeat in the kilombero valley, Tanzania. Conservation Biology 28:382-391. DOI: 10.1111/cobi.12197.

Nielsen U., Mertz O., Noweg GT. 2006. The rationality of shifting cultivation systems: labor productivity revisited. Human Ecology 34:201-218. DOI: 10.1007/s10745-006-9014-4.

Oxby C. 1985. Forest farmers: the transformation of land use and society in eastern Madagascar. Unasylva 37:42-51.

Passoni C., Rosenbaum A., Vermunt E. 2018. Empowering the inspection panel: The impact of the World Bank's new environmental and social safeguards. International Law and Politics 49:921-958.

Pham TT., Brockhaus M., Wong G., Le ND., Tjajadi JS., Loft L., Luttrell C., Assembe Mvondo S. 2013. Approaches to benefit sharing: A preliminary comparative analysis of 13 REDD+ countries. Bogor, Indonesia: Center for International Forestry Research (CIFOR).

Pollini J., Hockley N., Muttenzer FD., Ramamonjisoa BS. 2014. The transfer of natural resource management rights to local communities. In: Scales IR ed. Conservation and Environmental Management in Madagascar. London: Routledge, 172-192.

Poudyal M., Rakotonarivo OS., Rasoamanana A., Mandimbiniaina R., Spener N., Hockley N., Jones JPG. 2016a. Household survey and discrete choice experiment for investigating the opportunity cost of conservation restrictions in eastern Madagascar. Data Collection. DOI: https://dx.doi.org/10.5255/UKDA-SN-852435.

Poudyal M., Ramamonjisoa BS., Hockley N., Rakotonarivo OS., Gibbons JM., Mandimbiniaina R., Rasoamanana A., Jones JPG. 2016b. Can REDD+ social safeguards reach the "right" people? Lessons from Madagascar. Global Environmental Change 37:31-42. DOI: 10.1016/j.gloenvcha.2016.01.004.

Poudyal M., Rasoamanana A., Andrianantenaina SN., Mandimbiniaina R., Hockley N., Razafimanahaka JH., Rakotomboavonjy V., Rabakoson JC., Ambinintsoa J., Randrianarisoa M., Jones JPG. 2017. Household-level agricultural inputs-outputs, off-farm income and wild- 

harvested products survey in eastern Madagascar - ReShare. Data Collection. DOI: 10.5255/UKDA-SN-852790.

812 Pullin AS., Bangpan M., Dalrymple S., Dickson K., Haddaway NR., Healey JR., Hauari H., 813 Hockley N., Jones JPG., Knight T., Vigurs C., Oliver S. 2013. Human well-being impacts of terrestrial protected areas. Environmental Evidence 2:1-41. DOI: 10.1186/2047-2382-2-19.

815

816

817

818

819

820

821

822

823

824

825

826

Raboanarielina CM. 2012. The forgotten resource: Community perspectives on conservation and well-being in Zahamena National Park, Madagascar. Madagascar Conservation \& Development 7:70-78.

Rainforest Alliance. 2013. Reduced emissions from deforesation in the Ankeniheny-Zahamena Corridor, Madagascar - Validation Report: VCS Version 3.

Rakotomanana H., Jenkins RKB., Ratsimbazafy J. 2013. Conservation challenges for Madagascar in the next decade. Conservation Biology: Voices from the Tropics. NS Sodhi, L. Gibson and PH Raven (eds.):33-39.

Rakotonarivo OS. 2016. Improving the choice experiment method in assessing the local welfare impacts of forest conservation in low-income countries: Empirical evidence from Madagascar. United Kingdom and Denmark: Bangor University and University of Copenhagen.

Rakotonarivo OS., Bredahl Jacobsen J., Poudyal M., Rasoamanana A., Hockley N. 2018. Estimating welfare impacts where property rights are contested: methodological and policy implications. Land Use Policy 70:71-83. DOI: 10.1016/J.LANDUSEPOL.2017.09.051.

Rakotonarivo OS., Jacobsen JB., Larsen HO., Jones JPG., Nielsen MR., Ramamonjisoa BS., Mandimbiniaina RH., Hockley N. 2017. Qualitative and Quantitative Evidence on the True Local Welfare Costs of Forest Conservation in Madagascar: Are Discrete Choice Experiments a Valid ex ante Tool? World Development 94:478-491. DOI: 10.1016/j.worlddev.2017.02.009.

Rakotonarivo OS., Schaafsma M., Hockley N. 2016. A systematic review of the reliability and validity of discrete choice experiments in valuing non-market environmental goods. Journal 

http://dx.doi.org/10.1016/j.jenvman.2016.08.032.

839

Rasolofoson RA., Nielsen MR., Jones JPG. 2018. The potential of the Global Person Generated Index for evaluating the perceived impacts of conservation interventions on subjective wellbeing. World Development. DOI: 10.1016/j.worlddev.2017.12.032.

Ratsimbazafy LC., Harada K., Yamamura M. 2011. Forest conservation and livelihood conflict in REDD: A case study from the corridor Ankeniheny Zahamena REDD project, Madagascar. International Journal of Biodiversity and Conservation 3:618-630.

Republic of Madagascar. 2015a. Communique de Presse, Conseil du Governement - Mardi 28 Avril 2015 - Palais d'Etat de Mahazoarivo.

Republic of Madagascar. 2015b. Madagascar's intended nationally determined contribution.

Rerkasem K., Lawrence D., Padoch C., Schmidt-Vogt D., Ziegler AD., Bruun TB. 2009. Consequences of swidden transitions for crop and fallow biodiversity in Southeast Asia. Human Ecology 37:347-360. DOI: 10.1007/s10745-009-9250-5.

Revelle W. 2017.psych: Procedures for Personality and Psychological Research. Available at https://cran.r-project.org/web/packages/psych/index.html

Rose JM., Bliemer MCJ. 2013. Sample size requirements for stated choice experiments. Transportation 40:1021-1041. DOI: 10.1007/s11116-013-9451-z.

Roth MP. 2006. Prisons and prison systems: a global encyclopedia. Westport, Connecticut: Greenwood Press.

Le Saout S., Hoffmann M., Shi Y., Hughes A., Bernard C., Brooks TM., Bertzky B., Butchart SHM., Stuart SN., Badman T., Rodrigues ASL. 2013. Protected Areas and Effective Biodiversity Conservation. Science 342.

Sarrias M., Daziano R. 2015. gmnl: Multinomial logit models with random parameters. :R package. 
862 Scales I. 2014. The future of conservation and development in Madagascar: Time for a new 863 paradigm? Madagascar Conservation \& Development 9:5. DOI: 10.4314/mcd.v9i1.2.

864 Scarpa R., Rose JM. 2008. Design efficiency for non-market valuation with choice modelling: how 865 866 to measure it, what to report and why*. Australian Journal of Agricultural and Resource Economics 52:253-282. DOI: 10.1111/j.1467-8489.2007.00436.x.

867

868

869

870

871

872

873

874

875

876

878

879

880

881

882

883

884

885

886

887

888

Schmidt-Vogt D., Leisz SJ., Mertz O., Heinimann A., Thiha T., Messerli P., Epprecht M., Cu P Van., Chi VK., Hardiono M., Dao TM. 2009. An assessment of trends in the extent of swidden in Southeast Asia. Human Ecology 37:269. DOI: 10.1007/s10745-009-9239-0.

Schwitzer C., Mittermeier RA., Johnson SE., Donati G., Irwin M., Peacock H., Ratsimbazafy J., Razafindramanana J., Louis EE., Chikhi L. 2014. Averting lemur extinctions amid Madagascar's political crisis. Science 343:842-843.

Shackley P., Dixon S. 2014. The random card sort method and respondent certainty in contingent valuation: An exploratory investigation of range bias. Health Economics 23:1213-1223. DOI: 10.1002/hec.2980.

Shyamsundar P. 1996. Constraints on socio-buffering around the Mantadia National Park in Madagascar. Environmental Conservation 23:67-73.

Styger E., Rakotondramasy HM., Pfeffer MJ., Fernandes ECM., Bates DM. 2007. Influence of slash-and-burn farming practices on fallow succession and land degradation in the rainforest region of Madagascar. Agriculture, Ecosystems \& Environment 119:257-269. DOI: http://dx.doi.org/10.1016/j.agee.2006.07.012.

Sunderlin WD., Larson AM., Duchelle AE., Resosudarmo IAP., Huynh TB., Awono A., Dokken T. 2014. How are REDD+ proponents addressing tenure problems? Evidence from Brazil, Cameroon, Tanzania, Indonesia, and Vietnam. World Development 55:37-52. DOI: 10.1016/j.worlddev.2013.01.013.

Tabor K., Jones KW., Hewson J., Rasolohery A., Rambeloson A., Andrianjohaninarivo T., Harvey CA. 2017. Evaluating the effectiveness of conservation and development investments in reducing deforestation and fires in Ankeniheny- Zahemena Corridor, Madagascar. PLoS 
ONE. DOI: 10.1371/journal.pone.0190119.

890

891

892

893

894

895

896

897

898

899

900

901

902

903

904

905

906

907

908

909

910

911

912

913

914

TEEB. 2010. The Economics of Ecosystems and Biodiversity: Mainstreaming the Economics of Nature: A Synthesis of the Approach, Conclusions and Recommendations of TEEB.

Tubiello FN., Salvatore M., Ferrara AF., House J., Federici S., Rossi S., Biancalani R., Condor Golec RD., Jacobs H., Flammini A., Prosperi P., Cardenas-Galindo P., Schmidhuber J., Sanz Sanchez MJ., Srivastava N., Smith P. 2015. The contribution of agriculture, forestry and other land use activities to global warming, 1990-2012. Global Change Biology 21:2655-2660. DOI: $10.1111 / \mathrm{gcb} .12865$.

UNEP/CBD. 2000. Report of the fifth meeting of the conference of the parties to the Convention on Biological Diversity, Nairobi, 15-26 May 2000. UNEP - Convention on Biological Diversity.

UNFCCC. 2011. Report of the Conference of the Parties on its sixteenth session, held in Cancun from 29 November to 10 December 2010. United Nations Framework Convention on Climate Change.

US Government. 2016. Technical Support Document: Technical Update of the Social Cost of Carbon for Regulatory Impact Analysis Under Executive Order 12866. Washington DC.

Waldron A., Mooers AO., Miller DC., Nibbelink N., Redding D., Kuhn TS., Roberts JT., Gittleman JL. 2013. Targeting global conservation funding to limit immediate biodiversity declines. Proceedings of the National Academy of Sciences of the United States of America 110:12144-12148. DOI: 10.1073/pnas.1221370110.

White A., Martin A. 2002. Who owns the world's forests? Forest tenure and public forests in transition. Washington, DC: Forest Trends.

Widman M. 2014. Land Tenure Insecurity and Formalizing Land Rights in Madagascar: A Gender Perspective on the Certification Program. Feminist Economics 20:130-154. DOI: $10.1080 / 13545701.2013 .873136$. 
915 Gulland EJ. 2015. Guiding principles for evaluating the impacts of conservation interventions 916 on human well-being. Philosophical Transactions of the Royal Society B: Biological Sciences 917 370. DOI: $10.1098 /$ rstb.2015.0103.

918 World Bank. 2012. Plan de gestion environnementale et de sauvegarde sociale de la reserve de 919 ressources naturelles Ankeniheny Zahamena. Washington D.C.

920 World Bank. 2016. Implementation and completion results report for a third environmental 921 program support project (EP3). Washington, D.C.

922 World Bank. 2017a. Global Economic Monitor. Washington D.C.

923 World Bank. 2017b. The World Bank Environmental and Social Framework. Washington D.C.

924 Ziegler AD., Bruun TB., Guardiola-Claramonte M., Giambelluca TW., Lawrence D., Thanh Lam 925 N. 2009. Environmental consequences of the demise in swidden cultivation in montane 926 mainland Southeast Asia: hydrology and geomorphology. Human Ecology 37:361-373. DOI: 927 10.1007/s10745-009-9258-x.

928 


\section{Figure 1}

Map showing the location of the Corridor Ankeniheny Zahamena (CAZ) new protected area in eastern Madagascar.

The location of the four study sites, and the pilot sites are indicated. 


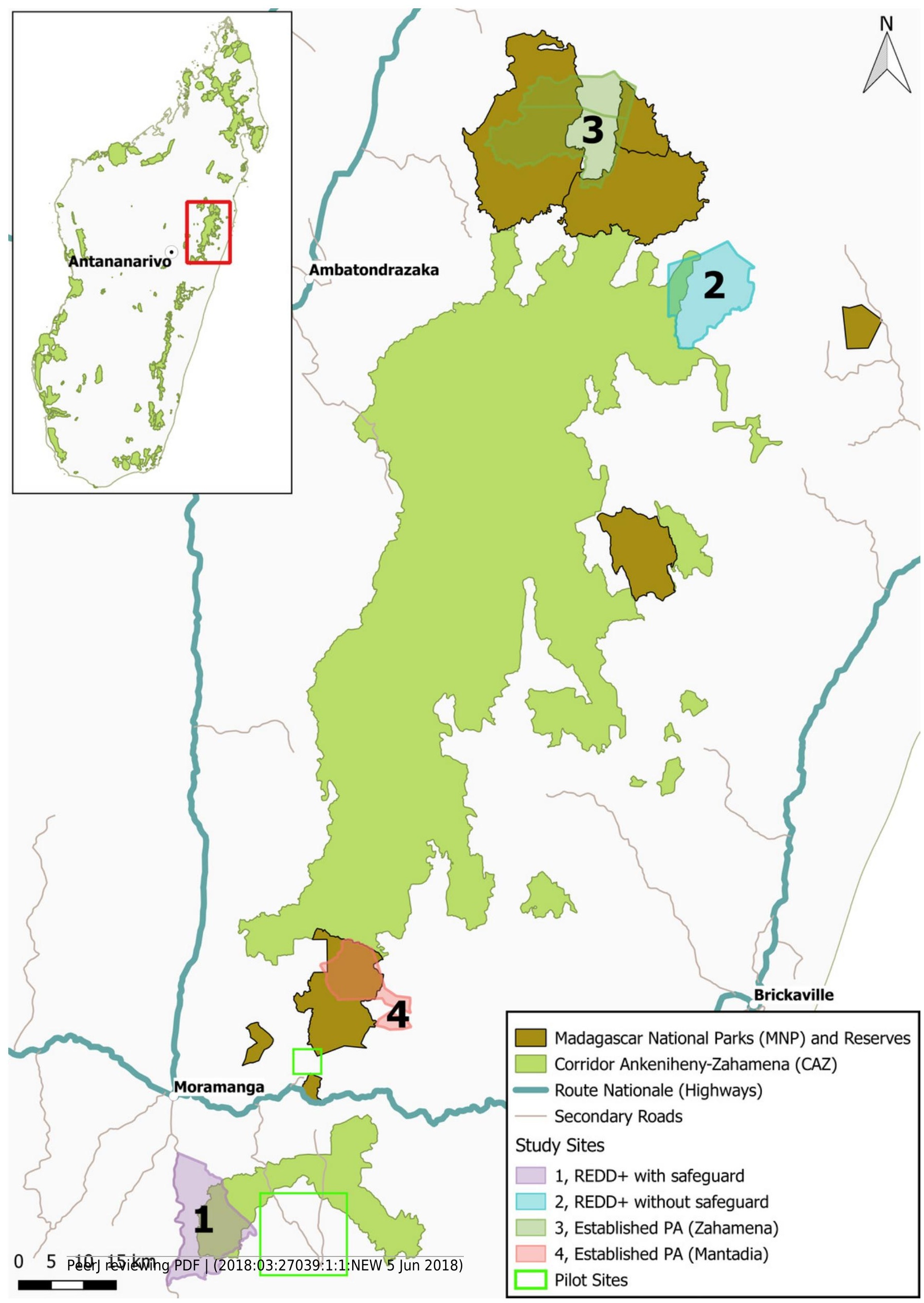


Figure 2 (on next page)

Indicators of wealth

Principal Component Analysis plots showing a) loadings of measures of wealth, b) individual household scores with a convex hull for each site. Wealth axis 1 can be interpreted as an overall measure of wealth (a higher value indicates higher household wealth while wealth axis 2 distinguishes between households with larger, higher quality houses and those growing irrigated rice and with high animal numbers. 


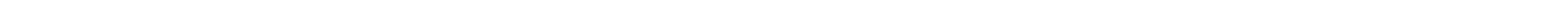


Figure 3 (on next page)

The Net Present Value (NPV) of net household opportunity cost of conservation restrictions estimated from the choice experiment.

a) The distribution of opportunity cost across the four study sites. b) Coefficient plot showing the effect of study site, distance of a household from the forest frontier, household age, education of the household head and the two wealth axes on the estimated household opportunity cost. 
a)

1,New PA

with safeguard

2,New PA

without safeguard

3,Established PA

(Zahamena)

4,Established PA

(Mantadia)
Manuscript to be reviey
New PA

with safeguard

New PA

without safeguard

Established PA

(Zahamena)

Established PA

(Mantadia)

Distance from forest

$(\mathrm{km})$

Household age

(decades)

Education

Wealth axis 1

Wealth axis 2
10000

20000 Net opportunity cost (\$) 
Figure 4(on next page)

The relationship between annualized household opportunity cost (from the discrete choice model) as a proportion of household income, plotted against household income (in 2015 US\$).

Median household income (US \$233) is indicated with a dashed vertical line. Lines are locally smoothed (Loess) fits to the data for the individual discount rate. 


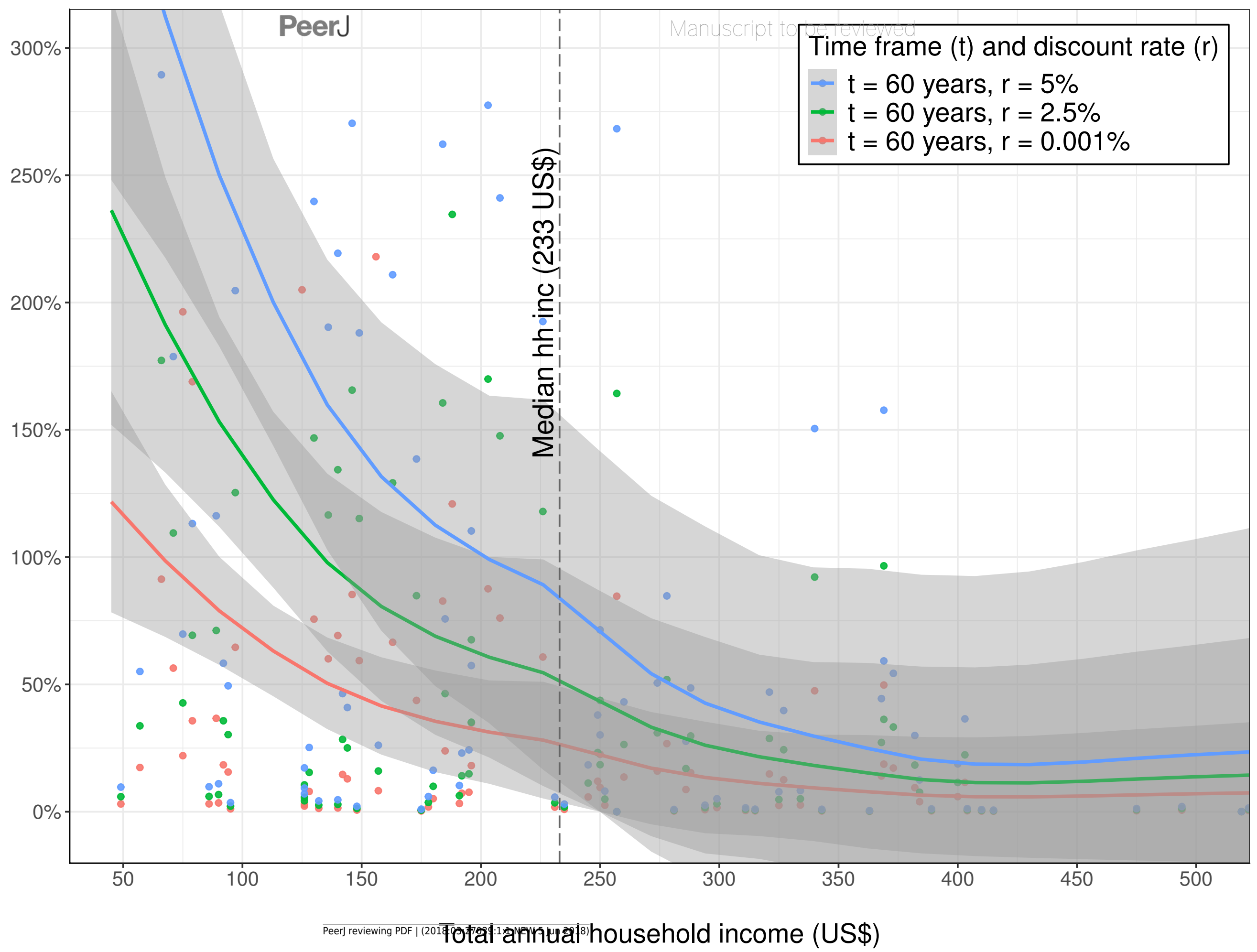




\section{Figure 5 (on next page)}

The underfunding of conservation compensation.

(a) A comparison between the number of households with NPV of opportunity costs greater than 2-4 times median annual household income, the number of households identified to receive compensation, and our estimate of the number fully compensated. (b) Comparison between the magnitude of the median net present value (NPV) of household opportunity cost (from our choice experiment), the maximum projected spend on compensation, and households' ex post valuation of the compensation provided (from our contingent valuation). The inset puts these figures in the context of our estimate of the carbon value per household of the REDD+ project in CAZ. Orange bars represent results from our survey and analysis, blue bars represent data obtained from published reports about the safeguarding process. 


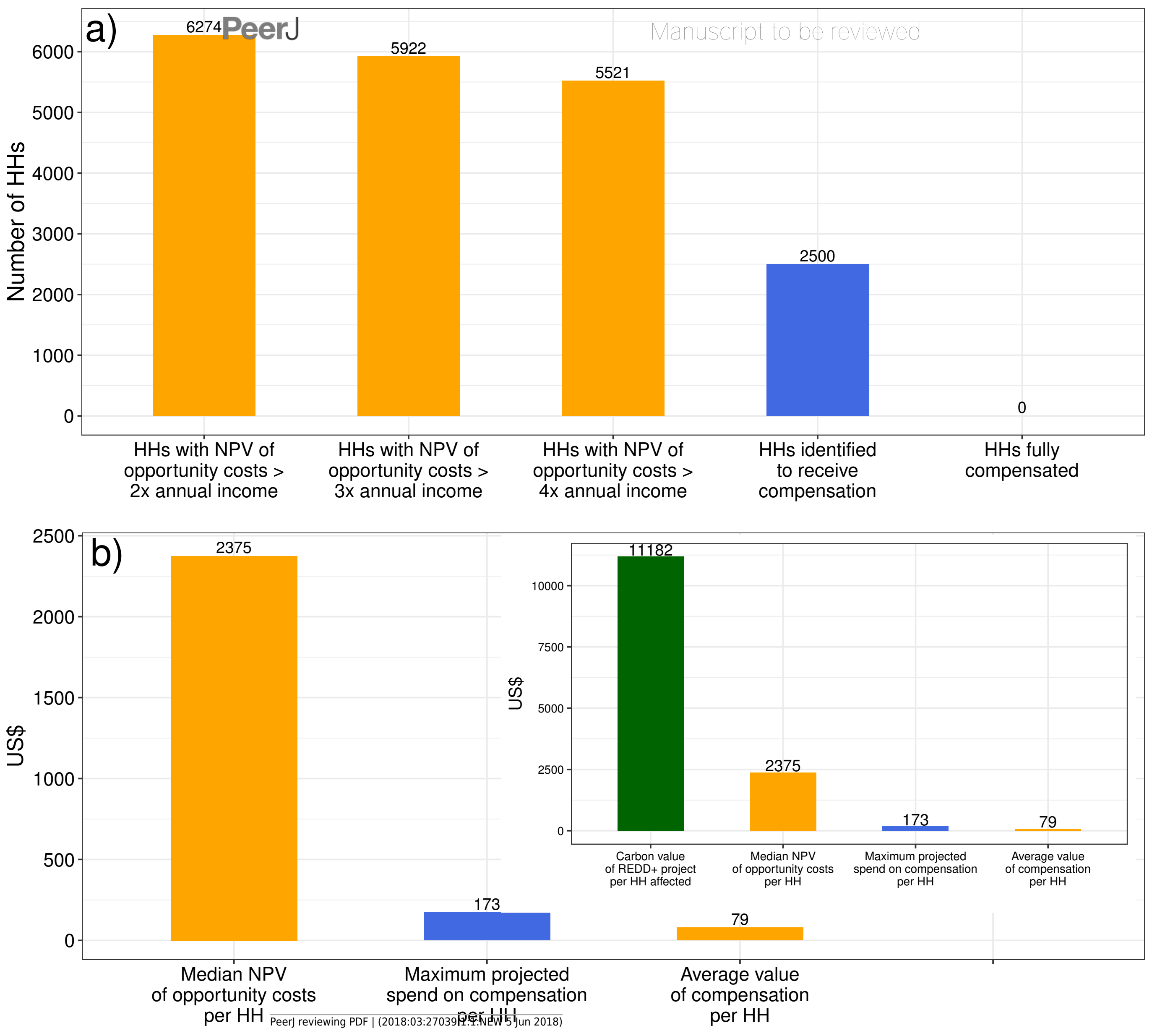




\section{Table $\mathbf{1}$ (on next page)}

Characteristics of the sites selected for this study, and sample sizes for various surveys 


\begin{tabular}{|c|c|c|c|c|c|c|c|c|}
\hline Site & $\begin{array}{l}\text { Fokontany, } \\
\text { (commune) } \\
\text { DISTRICT }\end{array}$ & $\begin{array}{l}\text { No. of } \\
\text { villages }\end{array}$ & $\begin{array}{l}\text { History of } \\
\text { conservation }\end{array}$ & $\begin{array}{l}\text { Enforcement of } \\
\text { conservation } \\
\text { rules }\end{array}$ & $\begin{array}{l}\text { Compensation } \\
\text { provided }\end{array}$ & $\begin{array}{l}\text { HH survey \& } \\
\text { choice } \\
\text { experiment } \\
\text { sample }\end{array}$ & $\begin{array}{l}\text { Agri. } \\
\text { survey } \\
\text { sample }\end{array}$ & $\begin{array}{l}\text { Contingent } \\
\text { valuation } \\
\text { exercise }\end{array}$ \\
\hline $\begin{array}{l}1, \text { New PA } \\
\text { with } \\
\text { safeguard }\end{array}$ & $\begin{array}{l}\text { Ampahitra } \\
\text { (Ambohibary) } \\
\text { MORAMANG } \\
\text { A }\end{array}$ & 8 & $\begin{array}{l}\text { Granted } \\
\text { temporary status } \\
\text { in } 2006, \\
\text { formally } \\
\text { gazetted in } 2015\end{array}$ & Weak & $\begin{array}{l}\text { Yes (World } \\
\text { Bank social } \\
\text { safeguards) }\end{array}$ & 102 & 25 & 62 \\
\hline $\begin{array}{l}2, \text { New PA } \\
\text { (no safeguard) }\end{array}$ & $\begin{array}{l}\text { Sahavazina } \\
\text { (Antenina) } \\
\text { TOAMASINA } \\
\text { II) }\end{array}$ & 7 & $\begin{array}{l}\text { Granted } \\
\text { temporary status } \\
- \text { in } 2006, \\
\text { formally } \\
\text { gazetted in } 2015\end{array}$ & Very weak & No & 95 & 40 & - \\
\hline $\begin{array}{l}\text { 3, Established } \\
\text { PA } \\
\text { (Zahamena) }\end{array}$ & $\begin{array}{l}\text { Antevibe \& } \\
\text { Ambodivoangy } \\
\text { (Ambodimanga } \\
\text { valo) } \\
\text { VAVATENINA }\end{array}$ & 7 & $\begin{array}{l}\text { Long history of } \\
\text { conservation } \\
\text { (since 1927) on } \\
\text { periphery of } \\
\text { Zahamena } \\
\text { National Park }\end{array}$ & $\begin{array}{l}\text { Relatively } \\
\text { strong }\end{array}$ & $\begin{array}{l}\text { Park entry fees } \\
\text { shared used to } \\
\text { fund local } \\
\text { development } \\
\text { projects }\end{array}$ & 152 & 37 & - \\
\hline $\begin{array}{l}\text { 4, Established } \\
\text { PA } \\
\text { (Mantadia) }\end{array}$ & $\begin{array}{l}\text { Volove \& } \\
\text { Vohibazaha } \\
\text { (Ambatavola) } \\
\text { MORAMANG } \\
\text { A }\end{array}$ & 3 & $\begin{array}{l}\text { Long history of } \\
\text { conservation } \\
\text { (since 1989) on } \\
\text { periphery of } \\
\text { Mantadia } \\
\text { National Park }\end{array}$ & $\begin{array}{l}\text { Relatively } \\
\text { strong }\end{array}$ & $\begin{array}{l}\text { Park entry fees } \\
\text { used to fund } \\
\text { local } \\
\text { development } \\
\text { projects }\end{array}$ & 104 & - & - \\
\hline
\end{tabular}




\section{Table 2 (on next page)}

Key socio-economic characteristics of the surveyed households

Where we don't have valid data for the full data set of 453 , the sample size is given in parentheses the $1^{\text {st }}$ column). For variables included in our combined poverty index we give details of how they were coded for inclusion in the PCA. 


\begin{tabular}{|c|c|c|c|}
\hline Variables & Description & Summary statistics & $\begin{array}{l}\text { Coding for use in combined } \\
\text { poverty index }\end{array}$ \\
\hline $\begin{array}{l}\text { Number of } \\
\text { rooms }\end{array}$ & $\begin{array}{l}\text { Total number of rooms (including } \\
\text { external kitchens) }\end{array}$ & $\begin{array}{l}\text { Median }=2, \\
\text { Mean }=1.90, \\
\text { Std. dev. }=0.96\end{array}$ & Continuous variable $(0-10)$ \\
\hline House quality & Type of roof in the primary dwelling & $77 \%$ thatch & $\begin{array}{l}\text { roof type (sheet metal }=2 ; \\
\text { thatch }=1)\end{array}$ \\
\hline $\begin{array}{l}\text { Food security } \\
(\mathrm{n}=452)\end{array}$ & $\begin{array}{l}\text { Number of months for which } \mathrm{HH} \text { has } \\
\text { enough to eat }\end{array}$ & $\begin{array}{l}\text { Median }=7, \\
\text { Mean=6.7, } \\
\text { Std. dev. }=2.93\end{array}$ & Continuous variable $(0-12)$ \\
\hline $\begin{array}{l}\text { Tropical } \\
\text { Livestock units }\end{array}$ & $\begin{array}{l}\text { Numeric variable indicating the total } \\
\text { livestock ownership of a household } \\
\text { measured as 'Tropical Livestock Unit' } \\
\text { (107). }\end{array}$ & $\begin{array}{l}\text { Median }=0.05, \\
\text { Mean }=0.42, \\
\text { Std. dev. }=1.15\end{array}$ & Continuous variable (0-14.2) \\
\hline Irrigated rice & $\begin{array}{l}\text { Whether the household has access to at } \\
\text { least one irrigated rice field }\end{array}$ & $63 \%$ no & $0=$ no; $1=$ yes \\
\hline $\begin{array}{l}\text { Access to } \\
\text { lighting }\end{array}$ & $\begin{array}{l}\text { Type of light and whether household } \\
\text { have sufficient light }\end{array}$ & $\begin{array}{l}\text { Median }=2, \\
\text { Mean }=1.96, \\
\text { Std. dev. }=1.05\end{array}$ & $\begin{array}{l}\text { Type of light (firewood }=0 \text {, } \\
\text { candle, petrol or torch }=1 \text {; solar } \\
\text { lamp or generator }=2 \text { ) AND } \\
\text { sufficient (never or rarely }=0 \text {, } \\
\text { sometimes }=1 \text {, mostly or } \\
\text { always }=2 \text { ) }\end{array}$ \\
\hline $\begin{array}{l}\text { 'Radio card' } \\
\text { mp3 player }\end{array}$ & $\begin{array}{l}\text { Binary variable indicating whether the } \\
\text { household has an mp3 device for } \\
\text { playing music. }\end{array}$ & $78 \%$ no & $0=$ no; $1=$ yes \\
\hline $\begin{array}{l}\text { Education } \\
\text { level }\end{array}$ & $\begin{array}{l}\text { Binary variable indicating low or high } \\
\text { level of education of the household } \\
\text { head. Low }(0)=0 \text { to } 5 \text { years of } \\
\text { schooling; High }(1)=6 \text { or more years } \\
\text { of schooling. }\end{array}$ & $90 \%$ low & NA \\
\hline $\begin{array}{l}\text { Household } \\
\text { size }\end{array}$ & $\begin{array}{l}\text { Total number of individuals considered } \\
\text { members of the household. }\end{array}$ & $\begin{array}{l}\text { Median=5, } \\
\text { Mean=5.5, } \\
\text { Std. dev. }=1.5\end{array}$ & NA \\
\hline Ethnic group & $\begin{array}{l}\text { Ethnic group to which the respondent } \\
\text { household head belongs }\end{array}$ & $\begin{array}{l}\text { Betsimisarika }=94 \%, \\
\text { Bezanozano }=3 \% \\
\text { Other }=3 \%\end{array}$ & NA \\
\hline $\begin{array}{l}\text { Primary } \\
\text { occupation }\end{array}$ & Main occupation of the household head & Agriculture $=90 \%$ & NA \\
\hline
\end{tabular}




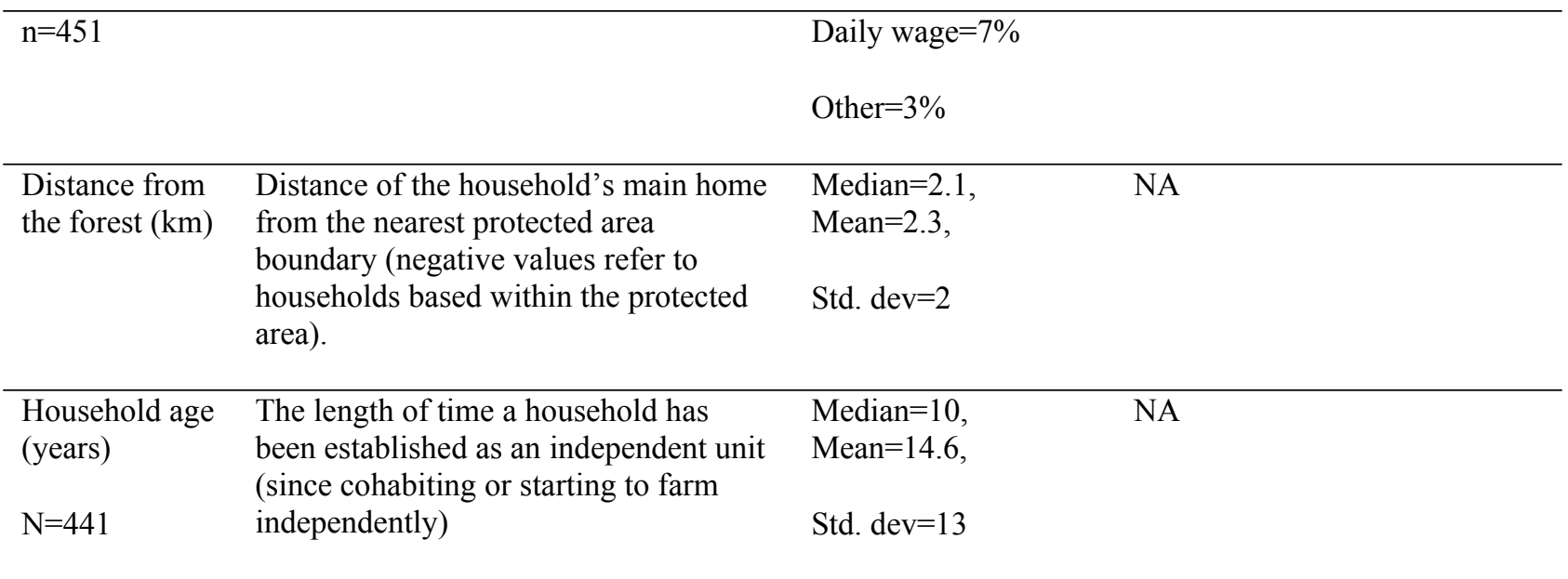

1 